$$
\text { on- } 1598
$$

$18 / a^{8}-7^{5}$

\title{
CALORIMETRIC MEASUREMENTS OF LASER ENERGY AND POWER - 1975 SUPPLEMENT
}

Stuart R. Gunn

July 30, 1975

\section{MASTLi:}

Prepared for U.S. Energy Research \& Development Administration under contract No. W-7405-Eng-48

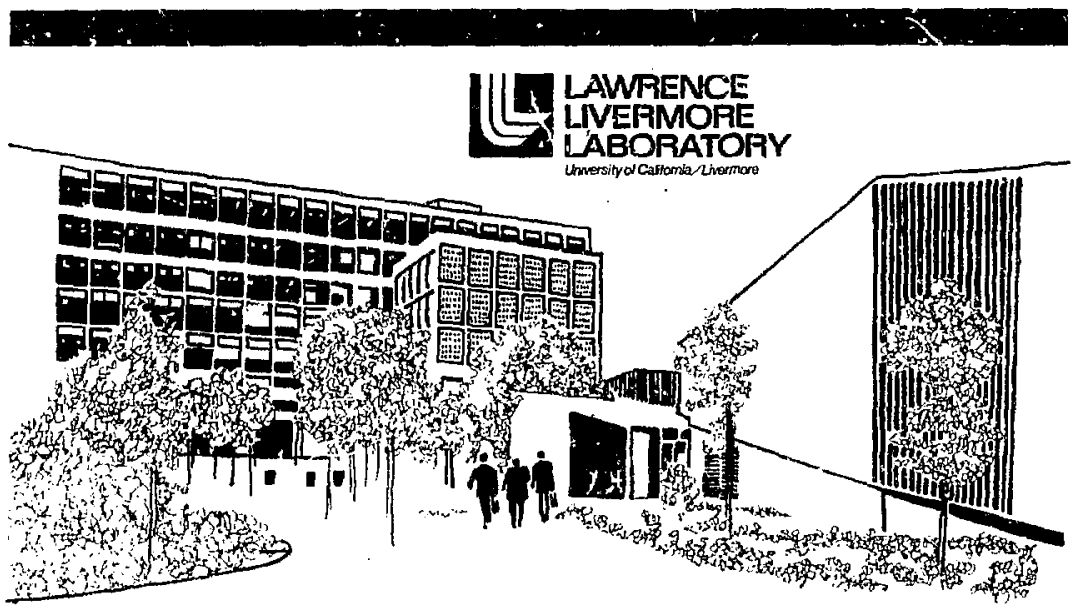




\title{
NOTICE
}

\begin{abstract}
"This report v'as prepared as an accouns of work sponsored by the United States Government. Neither the United States nos the United States Energy Research \& Development Administration, nar any of their employess, nor any of their contractors, incontractors, or their empluyees, mokes eny warranty, express or implied, or assumes any legal liability or responsibifity for the accuracy, completeness or usefulncss of any information, apparotus, product or process diaclosed, or repreqents that its use would not infinge privately-owned righty."
\end{abstract}

Printed in the United States of America Available from

National Technical Information Service

U.S. Department of Commerce 5285 Port Royal Road

Springfield, Virginia 22151

Price: Printed Copy $\$$; Microfiche $\$ 2.25$

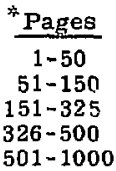

NTIS

Selling Price

$\$ 4.00$

$\$ 5.45$

$\$ 7.60$

$\$ 10.60$

$\$ 13.60$ 


\title{
近 \\ LAMPENCE LJVERMORE LABORATORY
}

University of Calitomia Livermona Caffornia 94550

UCRL -51873

\section{CALORIMETRIC MEASUREMENTS OF \\ LASER ENERGY AND POWER - \\ 1975 SUPPLEMENT}

\author{
Stuart R, Gunr
}

is. date: July 30, 1975

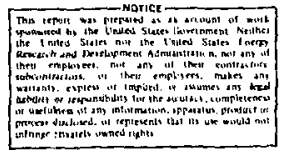




\section{Contents}

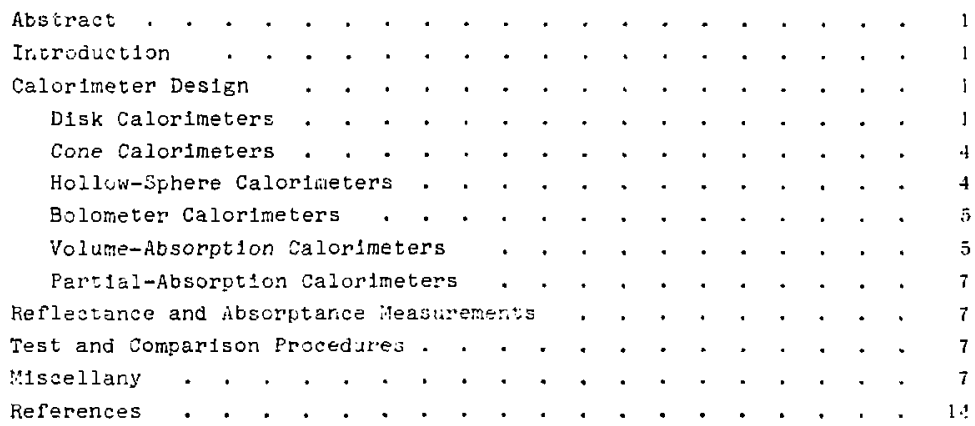




\title{
CALORIMETRIC MEASUREMENTS OF LASER ENERGY AND POWER - 1975 SUPPLEMENT
}

\author{
Abstract \\ The use of calorimeters for \\ measuring laser output energles and \\ powers is reviewed, primarlly for \\ the perlod 1972-1975 since prep- \\ aration of an earlier review.
}

\section{Introduction}

References 1-113 of this report were discussed in an earlier review. 114,115 The present review cuvers primarily papers that have been putlished sirce. It will also include sume earlier papers that were unavallable or were overlooked at that time.

Due to space limitations, the Hublished version 15 of the earlier review lneluded less reneral discussion of the principles of calorimetry than did the preliminary version. 114 Ii did, however, include several additional references; three of these $116-116$ are to books and a review article on calorimetrie principles, and seven $119-125$ are to articles speclflcally on zaser calorimetry. Discussion of these latter seven is repeated in the sections below. Seven rererences $6,21,23-25,27,28$ in the earlier version ${ }^{114}$ were elimInated in the process of abridgment to the later form. 115

Some papers are not readily avallable or are unavaliable in English, French, or German translation; in such cases, anc some others, the abstract is c1ted with the reference. In many of these cases the abstract provides ifte information about the apparitus.

\section{Calorimeter Design}

\section{DISK CALORIMETERS}

Jacob et al. 126 described twin calorimeters consisting of two anodized aluminum plates, $3.2 \mathrm{~mm}$ thick. A differential thermopile having Junctions spaced $25.4 \mathrm{~mm}$ apart in a square grid pattern on the back of each plate senses the temperature dit'ference. The 
sensitlvity was ealeulated from the mass and specific heat of the alumInum and the characteristics of the thermoplie materials, and was also checked by comparison with a commerclal pc er meter. The laser beam Impinges directly on the aluminum oxlde surface; the specuiar reflectivity of this was measured and found to vary from $1-3 \%$ in the 8.5-11-um region. The maximum acceptable energy density was calculated for short pulses as a function of pulse duration, the assumed limit being that which would give a temperature of $933 \mathrm{~K}$ $\left(660^{\circ} \mathrm{C}\right.$ ) (melting polnt of aluminum)

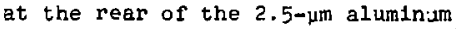
oxtde layer; this is about $3 \mathrm{~J} \cdot \mathrm{cm}^{-2}$ for 1-us pulses.

Gelst, Schmidt, and Case $127 \mathrm{de}-$ scribed a broadband twin radiometer having a recelving aavity approximately as shown in Fig. 1. The Inside of the cavity is coated with black paint, so most of the radiation $1 \mathrm{~s}$ absorbed on the low, nearly flat cone at the end of the oylindrical cavity; the cylindrical wall absorbs most of the radietion reflected at the first surface. The system thus approximates most closely a disk calorimeter, although It has some relation to the cone

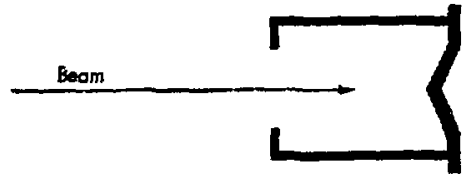

F1E. 1. Cup-shaped calorimeter, 127 and hcllow-sphere types. The base of the cavity includes a calibratine; heater, and the temperature is sensed with an electrorleposited radial thermopile. The instrument was aompared with the NBS C-series laser calorimeters ${ }^{13}$ using a 0.676-um cw laser bean; agreement was within the experimental uncertainty, $\sim 1.5 \%$.

West et al. described a related conflguration derfved from the earlier cone-and-tube instruments. 13 One version, ${ }^{228}$ Flg. 2, has an absorbing disk mounted at an angle to the beam and attached to a tube; both are black-palnted. Mounting the disk at an angle to the beam ensures that any specula: reflections from the metal, at holes in the paint, would strike the tube. Three of these and one of the older type are malntalned at the NBS as reference standards for calibration of other instruments. Another version, 129 also related to that of Ne1ll, 123 has a shallow polished conlcal mirror at the end of the cylinder to reflect and spread the Incident radiation onto the cyllndrical wall, Fig. 3. Both of these versions use a double-walled calorimetric body with a copper ring connecting the two walls. Thls construction serves to reduce systemstic exrors in comparing electrical heating callorations and laser beam inputs because the surface temperature pattern on the outer wall becomes largely independent of the location of the source of the heat on the Inner wall. 


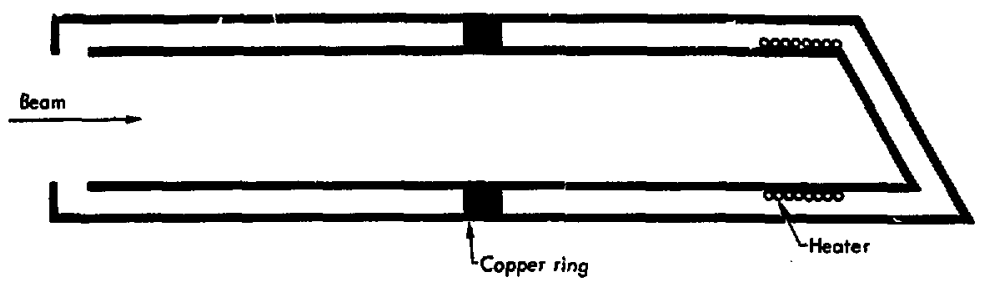

F1g. 2. Disk-end-tube calorimeter. $12 \hat{8}$

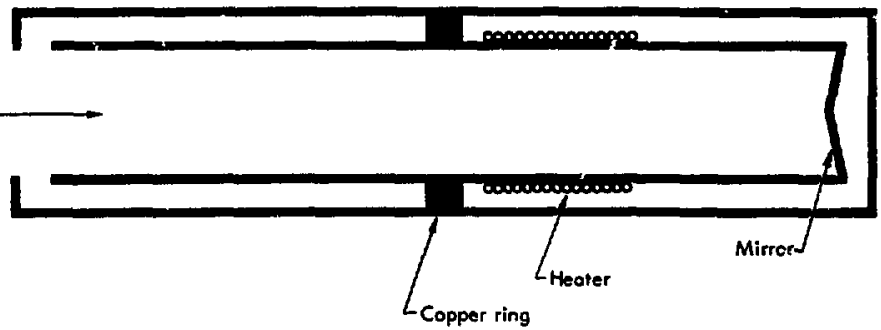

F1E. 3. Inverted-cone-and-tukt najorlme:er. 29

How1 ck1 130 develoned a

blackenad-diek calortineter at litalat

the temperature coeflictent of the fermltivity of a ferroelectric ceramic ror the temperature sersiri". Two plates of BaT1O 3 are sunawiched between two metal capa : Lor plates, one of which is blackened. The capactior is connected Into an ac bridge, the output of which is used to regulate the current in a heater between the two ceramic plates so as to malntain the capacitor at a constant elevated temperature. The reduction of the power required in the heater when radition 1mpinges on the tastrened int: is assumed to be ejuil to the radiati an fower. sahura1, Misuhash1, and Hondal 31 deseribei appatently the same culo:imetar as in an eirlier paper. 33 Zakurenke et aI. ${ }^{125}$ described a somewhat similar disk calorimeter with automatically cuntrolled leltier cooling, using a semiconductor thermontle.

Gardener and Harting ${ }^{121}$ descrlbed a disk calorlmeter, for beams of rast atoms, using an arrangement with a radal thermoplle and radial 
heat flow somewhat similar to those of Jennings et al. 1 and

Mefferd et al. 35

\section{CONE CALORIMETEAS}

Preston 132 studied the spectral response of cone calorimeters by comparison with a black radiation thermoplle, ushag flitered bands of broadband radiation peaked at 0.65 , 0.85 , and $1.2 \mathrm{\mu m}$. The results for the absorption efriciency of the cone were in good agreement with those calculated on the assunptions that the reflections are perfectly specular and that the effective average reflectivity of nickel for rays incident at 12 angles fror $7.5^{\circ}$ to $90^{\circ}$ is equal to that for normal Incidence.

Bout Ineau and Sauneur 133 degerdbed twin graphite cone salorimeterg. The Junctions of the Iron-constantan thermorile sre atcached at equal intervals aluitó a hel1x on the cone or at the center of segments of equal area. Callbration $1 \mathrm{~s}$ performed by dischirging a capacitor across electrodes around the opening and et the apex of the cune. Tha response to laser pilbes was found to be linear for energy dengit tes up to $0.5 \mathrm{~J} \cdot \mathrm{cm}^{-2}$ cor pulses $30 \mathrm{~ns} w 1 d e$, and less for shorter pulses. The response as a funstion of beam diameter was studied by placing a diverging lens in the beam and changing the position of the calorimeter. From comparisons of similar calorimeters in a splitbeam system it was ooncluded that the precision is imited to $-20 \%$, and the design is unsatisfactury for diameters greater than $50 \mathrm{~mm}$. A brief preisimary description was Biven of calorimeters of larget diameter using a flat graphlte disk with deep cireular Erosves glvir.c some cone eflect.

Ne11: ${ }^{123}$ descrited : : lorlmeter conslsting of an alumlat: :ilinder. blackened on the Inter.1.r and contalning a polished alumirum cone having a base diameter equal to that of the cylinder. Reflection from the exterior surface of the cone reduced the rlux intensl:y at the interior of the eyinder belos the threshold for damage ti. the ulackenea suritace.

Stricker and Rom ${ }^{124}$ desortted is calorimeter having a curveri is:as cone in which a thin sil trat as: of platinum on the interion rinctloned as a reststance the:mome:er; the response $t 1$ me was a rew $m+111$ s'sconds.

HOLLOW-SPHEAE CALORIHETERS

Smith at al. 134 described a large varlation of a hollaw-sphere calorimeter for powers from $0.3-100 \mathrm{~kb}$ at wavelengths of 1-11 um. The aperture dlameter is $10 \mathrm{~cm}$. The beam flrst strikes a cylindrical convex mirror and tren a sandblasted plate, to diffuse the beam and reduce the power density. The remalnder of the cavity wall conslsts of black-painted panels. Water is pumped through channels in 
iho witl and the temproralure rise I: mindred for 100-s inidiation

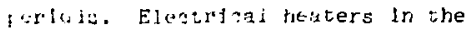
witer sireare are saed tol callbratior. Zelders and Hollatis des.rlied a his-ich-sphere calurlineter ror hiohriwe: beams. The bein sntarg ihrouith a relitlvely larze apersure ard strikes at curveo mirror of $y$ lisdrict iymmetry dreslgned to distribute the enerey infformly throuighow: the black-palnted interlor of the sphere. The temperawire rise is measured by resistance ihtwemetry, uslni" wire wound inzo a ir , ive in the wall. Calluratior by the method of mlxtures is sugces:ed: swirling a known amount of hot water in the sphere and meas: In the temperature lecrease of the water and resistanne Increase of the wirc. This method would be quick and easy, and adequate for moderito accuracy.

Drimb1 et al. 136 described a cillcrimeter consisting o." a $10 \mathrm{~mm}$ cube of thin cold foll with a $2-m$ hole, equivalent to a hollow sphere. Bïchl and Preirfer ${ }^{120}$ described a hollow-sphere calorimeter with distributed thermistors for the temperature measurement.

\section{BOLOMETER CALORIMETERS}

Koren et al. 137 duscribed a bolometer for laser pulses consisting of a thin black fllm of $\mathrm{y}_{2} \mathrm{O}_{5}$ evaporated onto a 10-mm-diam sapphire plate $8 \mathrm{um}$ thick. The resistance change $1 \mathrm{~s}$ measured with an ascillo- scope. Peak resistance chente yccurs in a few hundred microseconds, and the cime constant for coojing is aboit $5 \mathrm{~ms}$. The rolse level for small pulses is abou: $\pm 3 \mathrm{\mu J}$. Viclirskl and Badzlak 138 and Auzilis described other bolometrio invices for laser ererey measuremerts. Mrsuhashi and Sakura1 140 revitwed laser calorimetry and developec a "tw1sted-double-w1re" calorlmeter - possibly a ocilometer ¿ype - for pulsed ruby laser radiation. Kortum and wueller 141

reviewed recent literature on bolumeters and theinoelectris. detectors, for iaser and otlor measurements.

lushchikov et al. 142 descrioed a power meter for infrared lasers in which the laser beam is a tenuated, chopped, anc compared with the choppea beam from a black-body source, using a bolometer as the detector.

Farmer ${ }^{143}$ described a commercial version of che double cone bolometer, similar to that of Schmidt and oreenhow 88 and Schmidt. 87

\section{VOLUME-ABSORPTION CALORIMETERS}

Watt ${ }^{144}$ described calcoimeters for short, high-intensitv, $1.06-\mu \mathrm{m}$ pulses. The beam enters a cylindrical cavity througia a coaxial entry tube. The cavity is coated with a diffusing white paint. Suspended near the front of tre cavit:" is a ring of heat-absarbing glass whose inside diameter is greater than that of the entry tube; thus 
1t is not struck directly by the incldent beam but eventually absorbs most of the radiation scattered about in the cavity. The hot junctions of a thermopile are cemented to the ri.1g. The calorimeter contalus no electrical heater, but is calibrated by a split-beam comparlson with a cone calorimeter using short 1ntervals (0.1-1 s) of a $\mathrm{cw}$ beam.

Boulanger et al, ${ }^{14}$ describad a twin volume-absorbing calorlmeter for 10.6- $\mathrm{mm}$ beams. The absorbing material is Plexiglas or Mekrolon, 0.5 or $1 \mathrm{~mm}$ thlck, cemented to copper plates. Ar 1ron-constantan thermopile is used to measure the temperature difference setween the working and reference plates. Cal1bration is performed by calculiction from the masses and specific heats of the components or by use of an electrical heater on the copper plate.

Gunn $^{146}$ described twin calor1meters built in diameters from 13-330 $\mathrm{mm}$. Two anodized aluminum disks are suspenced in a massive aluminum houaing; on each are un1formly listributed 12 or 21 junctions of a chromel-constantan wire thermoplle. Callbrating heaters are located on the rims of the disks. The absorbing material is cemented to the fase of the alsk; various colored glasses were tested at $1.06 \mathrm{\mu m}^{146}$ and $0.46-0.69 \mu \mathrm{m} .147$ Three different glasses withstood energy densities up to about $60 \mathrm{~J} \cdot \mathrm{cm}^{-2}$ for 200-ps, $1.06-\mu \mathrm{m}$ pulses. The nolse level of the calorimeters 1s typically $10 \mathrm{LJ}$ fer square centimeter of absorber area. A more economically constructed version using commercial semiconductor thermoelectric modules has also been described. 148

Calorimeters of the same type but with different absorbing materials magnestum oxide, 1 thium fluoride, and various plastica - were also studied for use from $9.24-10.76 \mathrm{\mu m}$ with both $\mathrm{c} w$ and short pulse beams. 98 St1rred-11quid caiurimeters were also built and used with copper sulfate solution ${ }^{146}$ for $1.06-4 m$ beams and various orgaric liquids for 9.27-10.59 $\mathrm{\mu m}$. 98 The solldabsorber calorineters were also compared with a previously-described tubular calorimeter ${ }^{70}$ usine short intervals of ow beams at $1.06 \quad 1 / m^{147}$ and $9.7 .7-10.59 \mu \mathrm{m} .98$

Karlova and Kuz'mir 149 briefly described a saloplmeter using magnestum fluoride as a volume absorber for b1gh-power 10- $\mathrm{mm}$ pulies.

Johnson 350 and Relchelt et al. 151 described energy meters for 10.6-um pulses in which the energy is totally absorbed in a gus, sulfur hexafluoride. orfenberger et al. 152 described another in which pulsed beams are partially absorbed in a dilute mixture of propylene and hellum. In all of these the pressure increase rather than the temperature increase is measured. The type is capable of ready extension to large beam diametars and large pulse energies. Related to these eneriy meters is the use of various 


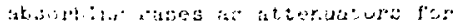

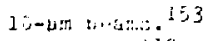

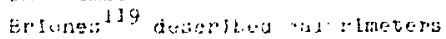
that ingrite ty treasulesne the volune or fressur" inclease of an atosorblir 11qu10.

PARTIAL-AB:SORITIOA OALOKI:AETEF:

Vallov and kalinints descrited a power-measurjne calorineter usine two mirrors; Lhts may be slmilar to that of Rasmussen. $\exists 9$

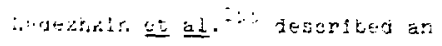

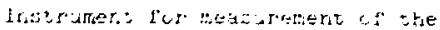

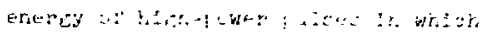

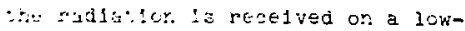

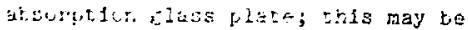

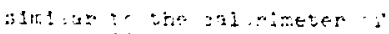
Euwaras. :

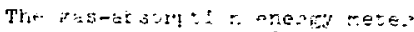

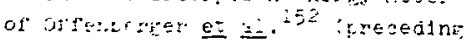

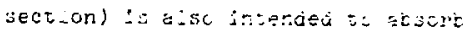
only a fracion af zre erergy ir: iransm: $t \geqslant c$ bear.

\section{Reflectance and Ȧbsorptance Measurements}

Calorimetric methods may be applied to the determination of the replection and yer diation losses frcm materials used as absorbers in laser caiorimeters. Jacob et al. 126 mounted a specjmen of anodized aluminum asorber absve a disk calorimeter ard surrounded the syectmen with a hemisphenical mirror to disct radiation rerlectea rrom the specimen onto the disk. A small

hole in the mirror admitted a lazer beam to the specimen. The system Eave an upper $11 \mathrm{mit}$ of $5 \%$ for the reflectance at $10.6 \mathrm{~km}$.

Bowlanger et al. 145 measured the reflection loss rrom their plasticplaie calorimeters by tilting the calorimeter at an angle of $5^{\circ}$ to the incident beam and placing a mirror so as to return the specularlyreflected component to the calorimeter absorber.

Gunn $^{146}$ deseribed a reflectance calorimeter consisting of a blackened metal cup, fitted with a thermoplie ano cal1t:kine heater, arranges to Intereet neariy ail of the specularl $\because \because-r e r l e c t e d$ and diffuselyrefiezed rodiation as we:l as excess thermit tajlaiton irom the neated surtace of sposimers of absonthe natertal. in hole in the cur admits the leser besn at an antle of $15^{\circ}$ to the siesfien, $w_{t} \mathrm{ch}$ Is mounted or an iliminim. ilsk flcted with 1:s un: hermofile ano calibrating heazer io measure the ausorbed enersy. Selarate measurements $\sim$ the specula? reficotance were also described.

West and Schiditizs have described in greater detall a previouslydescribed 13 procedure for usting as auxillary calorimeter to reasure the losses from blackened tube-cone and tube-disk calorlmeiers.

calorimetric methods have also been used for measuring the absorptivity of mirror materials. $41,156-107$ 


\section{Test and Comparison Procedures}

Many papers $13,127,129,146,168-172$ have dealt with electrical cal1bration of calorimeters and with techniques for comparing calorimeters and other power- and energymeasuring instruments in laser beams; a few key points will be mentioned here. In general, a split-beam arrangement must be used; a singlebeam system is usable only if the laser stability is better than the prectsion required of the comparison. The two calortmeters under compar1son may be interchanged between the two beams, or they may be interchanged in one beam while a third calorimeter is used as a monitor in the other beam. The calorimeters should be far enough from the laser to reduce the effect of laserflashlamp radiation to an acceptable level. Irises and entry tubes may be used to reduce the effects of variable extraneous radiation and air currents. The splitter and any windows in the system should be wedges, in order to avoid interference effects from parallel surfaces. The angle of incldence of the beam at the splitter should be small if the angle of polarization of the laser beam varies. A lens may be used in one or both beams and the position of the calorimeter varied to test the effects of variation of power-energy vensity. Irlses and central stops may be used to ensure that the beam lit's well within the aperture of the calorimeter; diffraction effects must be taken into account.

0 'Ne1l at al. ${ }^{173}$ have discussed samplens, attenuators, and methodology for diagnosties of high energy pulsed $\mathrm{CO}_{2}$ Iasers. Franzen 174 studied Fresnel beam splitters for the same.

\section{Miscellany}

Zakurenko et aㅡ. ${ }^{175}$ used an 1ce calorimater for laser energy measurements. In th1s system, the energy recelved by the calorimeter causes melting of 1ce, which is measured as a volume decrease in an 1ce-water mixture. The abstract does not indicate the type of recelver used within the alorimeiter to absorb the laser energy; but the virtues of $;.$ calorimeters include abllity to measure slow processes and leck of dependence of the response on the location of the deposition of heat, so an absorbing IIquid, such as an aqueous solution, or a contcal or other cavity could be used.

Several papers have wealt with pyroelectric detectors as applied to laser and other measurements. $122,176-180$

Blevin and Brown ${ }^{282}$ in a paper on determination of the StefanBoltzmann constant inalude some useful Information on black coat1ngs. 
Von Gutfeld 182 discovered a transverse thermoelectric voltage effect in evaporated molybdenum and tungsten films 1rradiated by short laser pulses; the phenomenon may be useful for detectors.

Several earlier papers have included signiflaant amounts of review material on calorimetric and other me uhods of laser power and energy mea surement. $23,25,27,28,183-185$ Three papers ${ }^{1}, 37,58$ referenced earlier 114,115 have been reprinted. 186

The designation of laser calorimeters as disk, cone, hollowsphere, bolometer, volume-absorption and partial-absorption types is rather arbitrary; there 1 s considerable overlap, and many instruments do not fit cleanld into any category. Table 1 presents a summary of some of the more important characteristics of most of the laser caloriweters described in the refierences. The following numbered paragraphs define the abbreviations used in the corresponding columns In Table 1 .

1. Perraps the most fundamental division is between calorimeters that absorb radiation at a surface (sur) and those that absorb it throughout a volume of material (vol).

2 . In the case of surface absorption, the absorbing arrace may be a bright metal (met) or may be blackened with some coating such as bleck palnt, anodlaing on aluminum, or enamel on copper wire (blk). The (blk) absorptivity is usually higher but the damage threshold lower than in the (met). In the case of volume absorption, the absorber may be a solld (soi), liquid (11q), or gas (gas).

3 . In the case of surface absorpilon, the radiation may strike the surface perpendicularly, or nearly so, with reflected energy belng lost, as in a disk calorimeter (dis). Various configurations may be used to increase the absorptance. These Include the cone (con) and hollow sphere (hol). A grooved disk (grv) gives some or the effect of ? cone. A cup (up) absorbs the radiation malnly on the blackened bottom, as in a disk calorimeter, but intercepts some of the scattered radiation on the sylindrical wall. An Inverted cone or convex mirror ( 1 nv) of polished metal within the calorimeter may be used to spread high-intensity radiation onto a blackened cylindrical or spherlcal wall. A bolometer of randomly packed Insulated wire, a "rat's nest" (rat), gives multiple raflections within the mass of wire. D1sks, cones, or hollow spheres may be constructed of randomly or $\Gamma^{\prime} \mathrm{S}^{-1}$ ularly arranged wire that serves both as the absorber and the thermometer or bolometer; the indentations of the resulting surface increase its absorptivity.

4. The calorimeter may be designed for total or near-total absor,$t$ ton of 1 ts laser beam (tot) or for partial absorption (par) with 
most of the beam continuing on, avaliable for other uses.

5. The measurenent may be of the power (pow) of a $\mathrm{cw}$ beam, or of the energy (en) of ane or more pulses or of a timed interval of a ew beam.

6. The calorimetric metnodology nay be 1soper1bollo (1 1 go) in which the temperature rise of the calorimetric body is measured, with some correction for heat lost during the rise. The steadystate conduction method (sst) is most often used for power measurements but may also be used for energy measurements by integrating the temperature-time curve, A particular case of the steady-state method is the 11quid flow (flo) method. In another isothormal method energy is measuied by observing the amount of phase change (pha), solld to
Iiquid or liquid to gas, that 1t causes.

7. The temperature measurement may employ a thermocouple (te), mult1Junction thermopile (tp), thermistor (tet), or metallic resistance thermonreter (res). A partioular case of the latter is the bolometer (bol). Or temperature change may be inferred by measurement of a change of volume ( $\mathrm{vah}$ ) or change of pressure (pch).

8. The calorimeter may incorporate a heater (htp) for cilibration with electrical enerey, or have no heater (noh). W1th appropriate clrcultry, the resistor of any bolometer-type calorimeter can be made to serve as its own beater; 1 t is sometimes unclear whether this has in fact been done. 
Table 1. Characteristics of laser calorlmeters.

\begin{tabular}{|c|c|c|c|c|c|c|c|c|}
\hline Reference & 1 & 2 & 3 & 4 & 5 & 6 & 7 & 8 \\
\hline 1 & vol & $11 q$ & - & tot & en & $1 s 0$ & tc & htr \\
\hline 1 & sur & blk & dis & tot & pow & sst & tc & noh \\
\hline 1 & sur & blk & con & tot & pow & sst & $\mathrm{tc}$ & $n \circ h$ \\
\hline 1 & sur & blk & con & tot & pow & 110 & tc & noh \\
\hline 5 & sur & blk & dis & tot & pow & sst & $t p$ & net \\
\hline 11 & vol & sol & - & par & en & Iso & $t p$ & noh \\
\hline 13 & sur & blk & con & tot & en & $1 \mathrm{so}$ & $t p$ & htr \\
\hline 14 & sur & met & $\operatorname{lnv}$ & tot & en & $1 s 0$ & $t p$ & htr \\
\hline 22 & Bur & blk & rat & tot & en & 150 & bol & noh \\
\hline 33 & sur & blk & dis & tot & pow & 1so & $t_{p}$ & htr \\
\hline 34 & $\mathbf{s u r}$ & blk & $d I s$ & tot & en & sst & cp & htr \\
\hline 35 & sur & blk & grv & par & pow & sst & $t_{p}$ & noh \\
\hline 35 & sur & met & grv & par & pow & sst & $t p$ & noh \\
\hline 37 & sur & blk & $\mathrm{d} 1 \mathrm{~s}$ & tot & pow & sst & tp & htr \\
\hline 38 & sur & blk & $\mathrm{grv}$ & tot & pow & sst & to & noh \\
\hline 39 & sur & blk & dis & tot & pow & sst & $t c$ & htr \\
\hline 40 & sur & blk & $d 1 s$ & tot & pow & Flo & $t_{c}$ & $h t r$ \\
\hline 41 & sur & $b 1 k$ & con & tot & pow & flo & tst & htr \\
\hline 41 & sur & met & dis & par & pow & flo & tst & htr \\
\hline 42 & sur & blk & $\mathrm{d} 1 \mathrm{~s}$ & tot & en & 1 so & $t c$ & noh \\
\hline 43 & sur & blk & cup & tot & en & $\pm s o$ & tst & $n t r$ \\
\hline 44 & sur & blk & con & tot & pow & sst & bol & htr \\
\hline 45 & sur & blk & con & tot & pow & sst & tc & non \\
\hline 46 & sur & met & $\operatorname{con}$ & tot & en & 1 so & tc & noh \\
\hline 47 & sur & blk & con & tot & pow & sst & $t=$ & noh \\
\hline 48 & sur & met & con & tot & en & 1so & tc & noh \\
\hline 49 & sur & blk & hol & tot & en & 1 so & $t c$ & noh \\
\hline 50 & sur & blk & Inv & tot & en & 1so & res & noh \\
\hline 51 & sur & blk & con & tot & en & Iso & tst & htr \\
\hline 52 & sur & b1k & con & tot & en & 1so & tst & htr \\
\hline 53 & sur & blk & $\operatorname{con}$ & tot & en & 180 & to & ntr \\
\hline 54 & sur & blk & con & tot & en & 130 & res & htr \\
\hline 56 & sur & met & con & tot & en & 150 & to & noin \\
\hline 58 & vol & 119 & - & tot & en & 1 so & tc & htr \\
\hline 59 & sur & blk & con & tot & pow & sst & $t p$ & htr \\
\hline
\end{tabular}


Table 1. (Conta.)

\begin{tabular}{|c|c|c|c|c|c|c|c|c|}
\hline Reference & 1 & 2 & 3 & 4 & 5 & 6 & 7 & 8 \\
\hline 60 & sur & net & con & tot & pow & sst & te & noh \\
\hline 61 & sur & blk & con & tot & pow & 110 & $\mathrm{tc}$ & noh \\
\hline 62 & sur & blk & con & tot & pow & $\$ 10$ & tc & htr \\
\hline 64 & $\operatorname{sur}$ & met & Brv & tot & en & 150 & tst & noh \\
\hline 67 & sur & met & con & tot & en & sst & $t p$ & htr \\
\hline 70 & sur & met & $\operatorname{con}$ & tot & en & 180 & $t_{p}$ & htr \\
\hline 71 & aur & met & hol & tot & en & 1so & tp & noh \\
\hline 72 & sur & met & hol & tot & pow & flo & res & htr \\
\hline 73 & sur & blk & rat & tot & en & 1so & bol & htr \\
\hline 74 & sur & $\mathrm{b} I \mathrm{k}$ & rat & tot & en & 180 & bol & htr \\
\hline 75 & sur & blk & rat & tot & en & 180 & bol & htr \\
\hline 76 & sur & blk & rat & tot & en & 180 & bol & htr \\
\hline 77 & sur & blk & rat & tot & en & 180 & bol & htr \\
\hline 78 & sur & b1k & $\mathrm{d} 1 \mathrm{~s}$ & tot & pow & sst & bol & htr \\
\hline 80 & sur & blk & $\mathrm{d}$ is & tot & pow & sst & bol & htr \\
\hline 81 & sur & bik & $\operatorname{con}$ & tot & pow & sst & bol & ntr \\
\hline 82 & sur & blk & con & tot & pow & sst & bol & htr \\
\hline 85 & sur & blk & con & tot & en & $1 \mathrm{so}$ & bol & htr \\
\hline 86 & sur & blk & hol & tot & en & Iso & bol & htr \\
\hline 87 & sur & blk & hol & tot & en & 180 & bol & htr \\
\hline 88 & sur & blk & hol & tot & en & 180 & bol & ntr \\
\hline $89 a$ & sur & blk & hol & tot & en & 180 & tst & noh \\
\hline $89 b$ & $\operatorname{sur}$ & blk & hol & tot & en & 180 & bol & htr \\
\hline 90 & vol & $11 q$ & - & tot & en & 1so & tst & non \\
\hline 91 & vol & $11 q$ & - & tot & en & 180 & $t p$ & htr \\
\hline 92 & vol & $11 \mathrm{q}$ & - & tot & en & 100 & veh & noh \\
\hline 93 & vol & $11 q$ & - & tot & en & 1so & veh & noh \\
\hline 94 & vol & $11 q$ & - & tot & en & 180 & veh & htr \\
\hline 95 & vol & $11 q$ & - & tot & en & pha & veh & noh \\
\hline 96 & vol & $11 q$ & - & tot & pow & 110 & te & htr \\
\hline 97 & rol & sol & - & tot & en & 150 & $t p$ & noh \\
\hline 98 & vol & Bol & - & tot & en & 1so & $t_{p}$ & htr \\
\hline 99 & sur & met & d1s & par & pow & 1so & tc & htr \\
\hline 102 & sur & met & dis & par & pow & get & bol & noh \\
\hline 104 & vol & ges & - & par & pow & 190 & pch & noh \\
\hline
\end{tabular}


Table I. (Contd.)

\begin{tabular}{|c|c|c|c|c|c|c|c|c|}
\hline Reference & 1 & 2 & 3 & 4 & 5 & 6 & 7 & 8 \\
\hline 119 & vol & $11 q$ & - & tot & en & $1 s 0$ & $p \circ b$ & htr \\
\hline 120 & sur & met & hol & tot & en & 150 & tst & noh \\
\hline 123 & sur & blk & $\ln v$ & tot & en & Iso & $t p$ & noin \\
\hline 124 & sur & met & $\operatorname{con}$ & tot & en & $1 s 0$ & bol & noh \\
\hline 125 & sur & blk & d1s & tot & pow & 1so & $t p$ & $h t r$ \\
\hline 126 & sur & blk & dis & tot & en & $1 \mathrm{so}$ & tp & non \\
\hline 127 & sur & bIk & cup & tot & pow & sst & $t p$ & ntr \\
\hline 128 & sur & blk & Inv & tot & en & 150 & tp & ntr \\
\hline 129 & sur & blk & cup & tot & en & $1 \mathrm{so}$ & $t_{p}$ & htr \\
\hline 130 & sur & blk & ais & tot & pow & 150 & - & $h t x$ \\
\hline 131 & sur & blk & d1s & tot & pow & 1 so & $t_{p}$ & ntr \\
\hline 133 & sur & blk & $\operatorname{con}$ & tot & en & 180 & $t_{p}$ & htr \\
\hline 133 & sur & blk & grv & tot & en & 180 & $t p$ & - \\
\hline 134 & sur & blk & Inv & tot & en & 150 & $r e s$ & ntr \\
\hline 135 & sur & blk & $\operatorname{lnv}$ & tot & en & 180 & res & noh \\
\hline 136 & sur & met & tol & tot & en & 1 so & to & htr \\
\hline 137 & sur & blk & d1s & tot & en & $1 \mathrm{so}$ & bol & rioh \\
\hline 143 & sur & b1k & hol & tot & en & 150 & bol & htr \\
\hline 144 & vol & gol & $=$ & $t, 0 t$ & en & 1 so & tp & noh \\
\hline 145 & vol & gol & - & tot & en & $1 \mathrm{so}$ & tp & htr \\
\hline 146 & vol & sol & - & tot & en & 150 & $t_{p}$ & htr \\
\hline 148 & vol & 801 & - & tot & en & 1so & $t p$ & htr \\
\hline 149 & vol & gol & - & tot & en & 180 & res & noh \\
\hline$I 50$ & vol & gas & - & tot & en & 180 & pch & noh \\
\hline 151 & vol & $\operatorname{gas}$ & - & tot & en & 1 so & peh & nob \\
\hline 152 & vol & gar & - & par & en & 1 so & pch & non \\
\hline
\end{tabular}




\section{References}

1. D.A. Jennings, E.D. West, K.M. Evenson, A.I. Rasmussen, and W.R. Stmmons, Laser Power and Energy Measurements, National Pureau of Standards, Tech. Note NBS-TN-382 (1969).

2. E.D. West and K.L. Churney, J. Mppl. Phys. 41, 2705 (1970).

3. E.D. West, Data Analysis for Isoperibolic Laser Calorimetry, National Bureau of Standards, Tech. Note NBS-TN-396 (1971).

4. S.R. Gunn, J. Chem. Thermodynamies 8 , 19 (1971).

5. J.S. Preston, J, Phys, E. 4, 969 (1970).

6. E.F. Westrum, Jr., G.T. Furukawa, and J.P. McCullough, Experinental Thermodynam1cs, 1. Calorimetry of Non-reacting Systems, J.P. McCullough and D.W. Scott, Eds., (Butterworths, London, 1968), pp. 133-214.

7. E.D. West and E.F. Westrum, Jr., Ib1d. pp. 333-367.

8. D.C. ainnings and E.D. West, Ibid. pp. 85-131.

9. J.S. Laughiln and S. Genna, Radiation Dosimetry. 2: Instrumentation, F.H. Att $1 x$ and W.C. Koesch, Eds. (Academ1c Press, New York, 1966), pp. $389-441$.

10. M. Jakob, Heat Transfer, Vol. 1 (John Wlley \& Sons, New York, 1949), pp. 522-542.

11. J.G. Edwards, J. Phys. E. 3, 452 (1970).

12. L. Hartshorn and A.G. MoN1ah, Expertmental Thermodynamics. 1: Calorimetry of Non-reacting Systems, J.P. MeCullough and D.W. Scott, Eds. (Butterworths, London, 1968), pp. 59-84.

13. E.D. West, W.E. Case, A.L. Rasmussen, and L.B. Schmidt, I. Res. Natl. Bur. Sta. A76, 13 (1972).

14. M.M. Birky, Appl. Opt. 10, 132 (1971).

15. D.C. Ginnings and E.D. West, Rev. Sc1. Instr. 35, 965 (1964).

16. E.D. West and S. Ishihera, Rev. Sc1. Instr. 40, 1356 (1969).

17. H.S. Carslaw and J.C. Jaeger, Conduction of Heat in Solids (Oxford Un1v. Press, London, 1959), p. 75.

18. J.F. Ready, J.Appl. Phys. 36, 462 (1965).

19. a. Varsi, Interaction of H1gh Intensity Laser Radiation with Metali1e Surfaces, NASA Contract Rept. NASA-CR-103951 (1969).

20. W.Y. Ramsey, Spocular Spectral Reflectance of Paints from 0.4 to 40.0 Microns, U.S. Dept. of Commerce Weather Bureau, Washington, D.C., Meteorologlcal Satell1te Rept. No. 32 (1964).

21. P.J. Batemin, Lasers and their Applications (Institute of Electrical Engineers, London, 1964), Paper 40, pp. 1-7.

22. D.E. Klllick, D.A. Batemen, D.R. Brown, T.S. Moes, and E.T. de 1a Porrolle, Infrared Phys. 6, 85 (1966). 
23. Q. B1rnbaum and M. B1rnba:2m, IEEE Proc. 55, 1026 (1967).

24. H.G. Heard, Lager Parameter Measurements Handbook (John W1ley Sons, New York, 1968).

25. L. Büttner, Intern. Elektron. Rundschau 22, 221 (1968).

26. B.F. Scott, Inst. Meah. Engr. (London), Proc. 183, 56 (1969).

27. A.V. Kubarev, A.S. Obukhov, A. Ya. Le1k1n, V.s. Solov'ev, and V.P. Koronkevich, Izmeritel. Tekhn. (11), 20 (.967); Engl. transl. Meas. Tech. (USSR), 1317 (1967).

28. R.A. Valitov, A.V. Kubarev, and A.S. Obykhov, Izmer1tel. Tekhn. (4), 28 (1970); Engl, transl. Meas. Tech., 523 (1970).

29. R.W. Z1mmerer, Laser Focus 2, 39 (1970).

30. R.W. Z1mmerer, Laser Focus 3, 25 (1972).

31. S.R. Gunn, Nucl. Instr. Methods 29, 1 (1964).

32. s.R. Gunn, Nuci. Instr. Methods 85, 285 (1970).

33. K. Sakura1, Y. Mitsuhash1, and T. Honda, IEEE Trans. Instr. Meas. 16, $212(1967)$.

34. J.I. Macqueron and A. Noua1lhat, Les Developpements Recents de la Microcalorimetrle et de la Themogenese (Centre National de la Recherche Selent1(1que, Par1s, 1967), pp. 31-40.

35. W.S. Mefferd, R.J. Rorden, and J.L. Hobart, U.S. Patent 3596514 $(1971)$.

36. A.A. Offenberger, Appl. Det. 2, 2594 (1970).

37. D.A. Jennings and E.D. West, Rev. Sc1. Instr. 41, 565 (1970).

38. W.C. Fr1eke, U.S. Patent 3508056 (1970).

39. S.D. Jacobs, AppI. Opt. 10, 2564 (1971).

40. J.D. R1gden and G. Moelier, IEEE J. Quantum Electron. 2, 365 (1966).

41. Y. Arata and I. M1yamoto, Technol. Rep. Osaka Un1v. 19, (BB7) 379 (1969).

42. D.M. Anderson and M.P. Bedesem, Am. J. Phys. 34, 296 (2966).

43. W. Ruderman, F. Gould, R. Soden, R. Webb, C. P1ke, and R. PItlak, Lasers and Applicatione, W.S.C. Chang, Ed. (Ohlo State University, Engineering Experiment Station, Columbus, Oh10, 1962), Pp. 20-34.

44. R. Now1ck1, Infrared Phys. 8, 223 (1968).

45. W.L. Elsemman, R.L. Bates, and J.D. Merriam, J. Opt. Soc. Ir. 53, 729 (1963).

46. B.F. Scott, J. Sa1. Instr. 43, 685 (1966).

47. W.L. E1senman and R.L. BateB, J. Opt. Soc. Am. 54, $1280(1964)$.

48. V.V. Bocharov, V.A. Katulin, and V.G. Smirnov, Prib. 1 Tekh. Ekep. (1), 171 (1967). Engl1sh transl. Instr. Exp. Tech. (USSA) 180 (1967).

49. V.S. Zuev and P.G. Kryukov, Pr1b. 1 Tekh. Eksp. (3) 188 (1963). Engl1sh transl. Instr. Exp. Teah. (USSR) 563 (1963). 
50. S. Koozekenan1, P.P. Debye, A. Krutchkoff, and M. Cljtan, Inst. Rad10 Eng. Proc. 50, 207 (1962).

51. T. I1 and S.D. Sims, Agpl. Opt. 1, 325 (1952),

52. J.A. Calviello, Inst. Elec. Electron. Eng. Proc. 21, 611 (1963).

53. J.G. Edwards, J. Sc1. Instr. 44, 835 (1967).

54. F. H1llenkamp, Actá Imeko 1, 417 (1967).

55. F. H1llenkamp, J. Phys, E. 1, 1022 (1968).

56. A.J. Detrio, U.S. Fatent 3391279 (1968).

57. E.D. West and D.C. Ginnings, Rev. Sc1. Instr. 28, 1070 (1957).

58. D.A. Jennings, IEEE Trans. Instr. Meas. 15, 161 (1966).

59. J.W. Stearn, J.Sc1. Instr. 44, 218 (1967).

60. A.L. Pugh, Jr., U.S. Patent 3624542 (1971).

61. F.A. Horrigan, C.A. Kle1n, R.I. Rudko, and D.T. W1lson, High Power Gas Laser Research, Raytheon Res. D1v. Rept. AD 676226 (1968), PP. 83-85.

62. J.J. Ehrlich, G.J. Hutcheson, Jr., C.M. Kust, T.G. Rr.berts, ard C.M. Cason III, U.S. Patent 3464267 (1969).

63. S.R. Gunn, High-Capac1ty Radiometric Calorimeters, Lawrance L1vermore Laboratory, Rept. UCRL-5375 (1958).

64. J.A. Ackerman, Appl. Opt. 3, 644 (1964).

65. E. Calvet, Expe \pm Imental Themochemistry, F.D. Rossini, Ed, (Intergolence, New York, 1956), pp. 237-286,

66. E. Calvet and H. Prat, Recent Progress In Microcalorimetry (Pergamon Press, oxford, 1963).

67. H. Tacholre, Compt. Fend. Acad. Sc1. (Par1s) 258, 6093 (1964).

68. F. Davo1ne, J.L. Macqueron, and A. Nouallhat, J. Phys. (Paris) 24, 1103 (1963).

69. E.D. West and D.A. Jannings, Rev, Sc1. Instr. 41, 142 (1970).

70. S.R. Gunn, Rev. Sc1. Instr. 43, 1523 (1972).

71. J,R. Hilson, J. Phys. E. E, 215 (1969).

72. H.A. Kellock, I. PhYs.E. 2, 377 (1969).

73. R.M. Baker, Electron., Peb. 1, 1963, pp. 36-38.

74. A.A, Besahaposhn1kov, A.E. Volosh1n, and I.K. Kuchuber1,a, Prib. 1 Tekh. Eksp. (5), 204 (1965). Englion transl. Instr. Exp. Tech. (USSR) 1233 (1965).

75. R.M. Beker, U.S. Patent 3282100 (1966).

76. S. Takenoto, W. Sasak1, and Y. Wa'tanabe, Bull. Univ, Osaka Prefegture A 13, 207 (3964).

77. A. Perain and B. Markov10, Elektrotehn1ka 20, 259 (1967).

78. W.R. Blevin anti W.J. Brown, J.Sc1. Inst. 42,19 (1965).

19. C. Allen, P, Areas, N. Wang, and G.C. Bradley, Appl. Opt. B, B13 (1969). 
80. Yu. A. Skiyarov, V.A. Sedel'nikov, and L.I. Kats, Prib. 1 Tekh. Eksp. (6), 165 (1965). English trans1. Instr. Exp. Tech. (JSSR) 1478 (1965).

81. R. Now1ck1, Electron.Lett. 3, 474 (1967).

82. R. Nowlok1, Electron.Lett. 4, 404 (1968).

33. R. Now1ck1, Infrared Phys. 9, 211 (1969).

84. R. Now1cki, IEEE Trans. Instr. Meas. 16, 238 (1969).

85. L.E. Balczewsk1, Acta Phys. Polon. 35, 325 (1969).

86. A.J. Schmidt and R.C. Greenhow, J.Sc1. Instr. 44, 468 (1967).

87. A.J. Schm1dt, U.S. Patent 3561265 (1971).

88. A.J. Schmidt and R.C. Greenhow, J. Phys.E. 2,438 (1969).

89. R.A. Kazaryan, E.S. Vardanyan, and F.P. Safaryan, Prib. 1 Tekh. Eksp. (3), 146 (1964). Engl1sh transl. Instr. Exp. Tech. (USSR) 636 (1964).

90. E.K. Damon and J.T. Flynn, Appl. Opt. 2, 163 (1963).

91. A.S. Obukhov and V.M. Kusov, Izmeritel. Tekh. 8, 34 (1970). Enzl1sh transl. Meas. Tech. $1164(1970)$.

92. B.F. Scott, J. 3c1. Instr. 43, 940 (1966).

93. R. S1gel, A Liquid Absorption Calorimeter for Laser Pusse Energy Measurements, Inst1tut. Iü Plasmaphysik, Garch:ng be1 Müi chen, IPP-3186 (1969).

94. J. Foster, C. Appleyard, and D.W.P. Jones, A Llquid Calorireter for the Measurement of Laser Enorey, Royal Alrcraft Establishment, Rept. RAE-TM-WE-1271 (1968).

95. E. Bayer and G. Scháck, T. Phys. E. 2, 208 (190́9).

96. S.J. Martinich, C.J. Johnson, and D.P. Ak1tt, Rev. Eu1. Instr. 40, 359 (1969).

97. L.C. de Benedictes, U.S. Patent 3575048 (1971).

98. S.R. Gunn, Studies of Calorlmcter Absonters for CW and Pulsed Co, Lagerg, Lawrence Livermore Laboratory, Fiet. UCRL-51854 (1575).

99. A.L. Rasmussen, Rev. So1. Instr. 4I, 1479 (1970).

100. A.I. Rasmussen, hev. Sc1. Instr. 42, 1590 (1971).

101. J.M. Davies and P.H. Peter, Appl. 20t. 10, 1959 (1971).

102. J.G. Siekman and R.E. Mor1Jn, Phill1ps Res. Repts. 2j, 375 (1968).

103. W, B. Gandrud, Appl, Opt. 9, 1936 (1970).

104. E. Quel, X. de Hemptinne, A. Foyt and M. de Hemptinne, Ann. Soc. Sc1. Bruxelies B3, (III) 388 (1969).

105. J, Cooper, J. Se1. Instr. 39, 467 (1962).

106. B.N. Morozov, Iamerttel. Tekhn. (10) 7 (1967). English transl. Heas. Tech. 1167 (1567). 
107. J.H. Ludlow, W.H. MItohell, E.H. Putley, and N. Shaw, I. Sc1. Instr. 44, 694 (1967).

108. R.W. Treharne and C.K. McKibben, V.S. Patent 3398231 (1968).

109. M.F. KImltt, J.H. Ludlow, and E.H. Putley, IEEE Pro. 5E, 1250 (1968).

110. A. Hadn1, Proc. Symp. Subm11l1meter Waves, J. Fox, Ed, (Polytechnic Press, Brooklyn, N.Y., 1970), pp. 25l-266.

111. E.H. Putley, Ib1d., pp, 267-280.

112. R.W. Astheimer and R.E. Buckley, Rev. Sc1. Instr. 38, 1764 (1967).

113. R.W. Astheimer and R.E. Buckley, U.S. Patent 3459945 (15TU).

114. S.R. Gunn, A Review of Calopimetric Measurements of Laser Energy and Power, Lawrence LIvermore Laboratory, Rept. UCID-16214 (1972).

115. S.R. Gunn: J. Phys. E: Se1. Instr. 6, 105 (1973).

116. F.D. Rossin1, Ed., Experimental Thermochemistry 1 (Intersolence, New York, 1956).

117. H.A. Skinner, Ed., Experimental Thermochemistry 2 (w1ley Interscience, New York, 1962).

118. J.M. Sturtevant, Physical Method of Chemistry 1 (5). A. Welssberger and B.W. Rossiter, Eds. (Wlley Intersclence, New York, 1971),

pp. 347-425.

119. R.A. Briones, U.S. Fatent 3670570 (1972).

120. K. Büchl and H.-J. Pfelffer, Z. Angek. Phys. 32, 359 (1972). Engl1sh transi., Lawrence LIvesuore Laboratory, Rept. UCRL-Trans-10624.

121. J.E. Gardener and E. Harting, J. Phys, E: Sc1. Instr. 5, 712 (1972),

122. J.L. Lachambre, Rev. Sc1. Instr. 42, 74 (1971).

123. A.H. Ne111, Jr., Appl. Opt, 9, 2392 (1970).

124. J. Stricker and J. Rom, Rev. Sc1. Instr. 43, 1168 (1972).

125. O.E. Zakurenko, R.A. Velitov, A.S. Arzumanov, and V.M. Kuz'mlchev, Izmer1tel. Tekhn. 14, 21 (1971). Engl1sh tranal. Meas. Tech. 14, 30 (1971).

126. J.H. Jacob, E.R. Pugh, J.D. Daugherty, and D.B. Northam, Rev, Sict. Instr. 44, 471 (1973).

127. J. Gelst, L.B. Schm1dt, and W.E, Case, Appl. Opt. 12, 2773 (1973).

128. E.D. Weat and L.B. Sehnidt, J. Opt. Soc. Am. 65, 573 (1975).

129. E.D. Wost and W.E. Case, IEEE Trans. Instr. Meas. IM-23, 422 (1974).

130. R. Nowloks, Electron Lett. (OB) I, 647 (2971).

131. K. Sakura1, Y. M1tsuhash1, and T. Honda, Bull. Electrotech. Lab. (Japan) 32, 66 (196B); Electrical and Electronics Abs. 71, 24413 (1968).

132. J.S. Preston, J. Phya. E: Sa1. Instr. 2, 2014 (1972).

133. J.L, Boutineau and R. Sauneur, Calorimetres a Cones de araphite pour Laser. Comiseariat a 1 'Energle Atomique (Franje) Rept. CEA-CONF-2056 (1972). 
134. R.L. Sm1th, T.W. Russell, W.E. Case, and A.L. Rasmussen, IEEE Trans. Inst. Meas. IM-21, 434 (1972).

135. G.W. Zelders, Jr. and R.A. Hrila, U.S. Patent 3763685 (1974).

136. J. Domb1, L. Gat1, I. Ketskemety, I, Szalma, and L. V1ze, Acta Fhys. Chem. Szeged (Hungary) 16, 3 (1970).

137. G. Koren, Y. Yacoby, H. Lotem, M. Kosower, and G. Greenwala, App1. Phys. Lett. 23, 73 (1973).

133. W. Wolinskl and W. Badzlak, Pomlary, Automat., Kontr. 12, 44 (2966). (In Pol1sh) Chem. Abs. 67, 26449 (1967).

139. L. Muz11, Note Recens. Not. (Italy) 15 (1), 49 (1966) (In Italian). Electr. Electron. Abstr. 69, 14116 (1966).

140. Y. Mitguhash1 and K. Sakura1, Bul1. Electrotech. Lab. (Japan) 32, .82 (1968) (In Japanese). Ejectr. Electron. Abstr. I1, 24412 (1968),

141. H. Kortum and J.E. Mueller, Proc. IMEKo (Int. Meas. Confed.) Symp. Fhoton Detectors, 5th 2, 306 (1971). Chem. Abs. 26, 160166 (1972).

142. I.I. Lushchtkov, S.V. Mamak1na, N.G. Mansvetov, and T.D. Prokof'yeva, Opt.-Mekh. Prom.-st (USSR) 40 (8), 27 (1973). Engl1sh translation, Sov. J. Opt. Technol. 40, 489 (1973).

143. B. Farmer, Opt. Laser Technol. (GB) 3, 224 (1971).

144. B.E. Watt, Appl. Opt. 12, 2373 (1973).

145. P. Boulanger, A. Heym, J.-M. Mayor, and Z.A. Pletrzyk, J. Phys. E: Se1. Instr. 6, 559 (1973).

146. S.R. Gunn, Rev. Sc1. Instr. 45, 936 (1974).

147. S.R. Ounn, Studies of Laser Calorimeters using Glass Absorbers and Black-Painted Absorbers from 0.46 to 1.06 Micrometres, Lawrence Livermore Laboratory, Ropt. UCRL-51613 (1974).

148. S.R. Gunn, Lasen Calonimeters Using Commerclel Thermoelectric Modules, Lawrence L1vermore Laboratory, Rept. UCID-16608 (1974).

149. E.K. Karlova and G.P. Kuz'min, Prtb. Tekh. Eksp. (5), 165 (1974). English trans1. Instr. Exp. Tech. 17, (5) 1443 (1974).

150. D.C. Juhnson, Canadian Pet. 919452 (1973).

151. W.H, Re1chelt, E.E. Stark, Jr., and T.F. Stratton, Opt.Comm. 11, $305(1974)$.

152. A.A. Orfenberger, P.R. Smy, and N.H. Burnett, Rev. Sa1. Instr. 46, 317 (1975).

153. A.M. Robinson and M. Nohr, Rey. So1. Ingtr. 45, 1605 (1974).

154. R.A, Valitov and Yu. A. Kalinin, Red1otekhnika, Kharkov (USSR)

60 (1973). (In Ruesian). Phys. Abstr. 76. 7396 (1973).

155. Yu. M. Nadezhk1n, R,A. Val1tov, L.A, Baryshev, and V.K. N1koloaev, Rad lotekhnike, Kharkoy (USSR) (24) 69 (1973). (In Russ1an). Phys. Abstr: 16, 73797 (1973). 
156. M.A. Blond1, Phys. Rev. 102, 964 (1956).

157. M.A. Blonds and J.A. Rayne, Phys. Rev. 115, 1522 (1959).

158. K. Schröder and D. önengitit, Phys. Rev. 162, 628 (1967).

159. L.W. Bos and D.W. Lynch, Phys. Rev. Lett. 25, 156 (1970).

160. 0. Hunder1, Rev. Sc1. Instr. 42, 1596 (1971).

161. A.I. Braunstein and M. Braunste1n, J. Vac. So1. Tech. 8, 412 (1971).

162. H. Gentsch and J.C. Sna1th, J. Phys. E: Sc1. Instr. 5, 33 (1972).

163. L.L. N1chols, C.A. Rateliffe, and R.L. Gordon, Appl. Opt. 12, 2232 (1973).

164. R.A. HcAfma:1, App1. Opt. 13, 1405 (1974).

165. P.0. Nilsson, Solid State Physics 29, H. Ehrenreich, F. Seitz and D. Turnbull, Eds. (Academic Press, New York, 1974), pp. 139-234.

166. H.G. L1pson. L.H. Skolnik, and D.L. St1erwalt, Appl. Opt. 13, 1741 (1974).

167. T.T. Sa1to, A.B. Callender, and I.B. Simmons, AgpI. Opt. 14, 721 (1975).

168. E.D. West, Elect.-Opt. Syst. Des. 4 (11) 14 (1972).

169. S.E. Smathers and G. Maksymonko, IEEE Trans. Instr. Meas. IM-21, 430 (1972).

170. W. Blackmon, Proc. Elect.-Opt. Syst. Des. Conf., 5th, New York, I973 (Industrial and Sclentifle Conference Management, Inc, Chicago, 1973) p. 265-274. J. Curr. Laser Abstr. 11, 33 (197't).

171. T.W. Russell, Elect,-Opt. Syst, Des. 6 (8) 28 (1974).

172. R.H. James, O.L. Ellingson, and K.W. Peterson, J.Am. Ind. Hyg. Assoc. 30, 327 (1974).

173. F.W. O'Ne1l, H. Klelman, L.C. Marquet, C.W. Kildine, and D. Northam, Appl. Opt. 13, 314 (1974).

174. D.L. Franzen, Appl. Opt. 24, 647 (1975).

175. O.E. Zakurenko, V.M. Kuz'michev, and R.A. Valitov, Radiotekhnika (Kharkov, USSR). (11) 100 (1969). (In Russ1an). J. Curr, Laser Abstr. Z. 37 (1970).

176. W.M. Doyle, Opt. Spectre 6 (11) 21 (1972).

17\%. B.C. MeIntosh and D.W. Sypek, Laser Focus 8 (12) 38 (1972).

178. C.B. Roundy and R.L. Byer, Appl. Phys. Lett. 2l, 512 (1972).

179. A. Shaulov, A. Rogentirel, and M. Sinhony, I. Appl. Phys. 43, 4518 (1972).

180. R.J. Phelan, Jr., R.L. Peterson, G.P. Kle1n, C.A. Hamilton, and a.W. Day, Proc. Elect.-Opt, Syst. Des. Conf., 5th, New York 1973 (Industrial and Sclentific Conference Management, Inc., ChIcago, 1973), p. 117-123. J. Curr. Laser Abatr. 11, 33 (1974).

181. W.R. Blevin and W.J. Brown, Metrolog1a Z, 15 (1971). 
182. R.J. von Gutfeld, Appl. Phys. Lett. 23, 206 (1973).

183. A.V. Koubarev, A.S. Obcukhov, and E.I. Ivlev, Electron. I'schnol. (Poland) 2 (2/3) 165 (1969).

184. L. Balczewsk1, Postepy Fiz. (Poland) 20, 49 (1969) (In Polish). Phys. Abstr. ⒊ 29532 (1970).

185. R.A. Valitov, Yu.A. Kalinin, and V.M. Kuz'michev, Izmeritel. Tekhn. (5) 37 (1965). Eng11sh transl. Meas. Tech. 438 (1965).

186. H.K. Hammond, III and H.L. Mason, Eds., National Bureau of Standards Special Publication 3007 Selected NBS Papers on radiometry and Photometry (1971).

$\mathrm{RBC} / \mathrm{h}, \mathrm{d} / \mathrm{la}$ 